\title{
Viden om fodbold
}

\author{
af Anny Hedegaard Hansen
}

Når man som kvinde bliver bedt om at anmelde en bog, med den motivering at den teoretiserer over mænd og mandlighed, har det selvfølgelig en polemisk værdi. Men der er også en fare for at cementere sig selv i en formodet viden om kvindelighed og på det grundlag vurdere Karl Christensens formodede viden om mandlighed. Jeg opdagede derfor med nogen lettelse, at Fodboldspillet - teori, historie og fascination kun perifert er en ,mandebog“.

Bogen bærer i høj grad præg af det anstrengte forhold universitets- og venstrefløjspuritanere i nogle år havde til konkurrence- og eliteidræt, herunder fodbold (og i øvrigt stort set al anden aktivitet, der ikke havde et erklæret revolutionært mål). Men mens man terpede Kapitalen på universiteterne, fortsatte spillet dog uanfægtet på de danske fodboldbaner.

Denne akademiske holdning til spillet vendte i takt med universitetsmarxismens forfald, således at man i dag kan finde nogle af de mest fanatiske roligans på den universitære venstrefløj.

Denne vending har krævet noget retfærdiggørelse, mest markant i H.-J. Nielsens Fodboldenglen, og KCs bog fortsætter arbejdet med at ,bevise“ at fodboldspillet ikke længere er fordummende. Der arbejdes stadig på 70ernes efterdønninger.

I sin bog forsøger KC at få både det dårlige og det gode ved fodboldspillet med. To hovedstrømninger går igennem hele bogen: koldstrømmen og varmestrømmen kalder KC dem selv.

Bogen er inddelt i tre hovedafsnit: 1. fodboldspillets teoretikere 2. fodboldspillets historie og 3 . det nuværende fodboldspil.

I bogens teoretiske afsnit indføres vi i fire forskellige teoretiske retninger: den marxistiske ideologikritik (repræsenteret v. G. Vinnai), den civilisationsteoretiske (N. Elias, E. Dunning, W. Hopf), den strukturhistoriske (H. Eichberg) og de engelske sportskulturanalyser. Det er hovedlinierne, der skitseres i afsnittet, idet det er et kæmpe område, KC her forsøger at beskrive på tyve sider. Men som en indføring er det udmærket, man får indblik i de 
forskellige retningers forskelle og ligheder. Det kan dog til tider være svært at følge argumentationerne på dette overordnede plan, nok også fordi KC hovedsagelig er refererende uden selv at komme frem med de store overvejelser. Dette afsnit sammen med en ekskurs om utopien danner baggrund for de videre analyser bogen igennem.

I sin ,Ekskurs: det utopiske perspektiv“" kommer KC selv mere frem, efter først at have skabt rum for denne utopi $i$ civilisationsteoretikernes og kulturhistorikernes fritidsbegreb. Disse opfatter fritiden som konkret fri tid, der åbner for udfoldelsesmuligheder og selvbestemmelse i modsætning til G. Vinnais bestemmelse af sporten som dobbeltarbejde. Civilisationsteoretikerne og strukturhistorikerne siger dog ikke selv noget om det utopiske $i$ sporten.

KC bevæger sig med utopien ud i oplevelserne - ud i legen. Det er en ekskurs i den videnskabelige diskurs, fordi videnskaben ikke kan indoptage utopien. Det er af kærlighed til og fascination af fodboldspillet, at KC bevæger sig herud for at understrege dét væsentlige $\mathrm{i}$ spillet, som det sidste årti har skubbet til side.

At gøre opmærksom på fodboldspillets anden side - legen, sammenholdet, de store og små oplevelser - det er også nok. Men det kan virke lidt anstrengt at påklistre mærkaten 'utopi' for herefter blot at bruge det som modvægt til den marxistiske ideologikritiks negative bestemmelse af sporten. Sporten er både systembevarende og frigørende/forandrende, konkluderer KC flere steder. Det er imidlertid lidt svært at få fat på, hvad det så er, der frigøres og forandres.

Ydermere mener jeg, at KC med sin utopi letter fra sit teoretiske ståsted for aldrig at komme tilbage. Det ville have været nyt og overskridende, hvis KC havde brugt sin ekskurs til at udfordre videnskaben - eller i det mindste ikke blot tage afstand fra den, fordi den ikke levner plads for hans utopi:

Sådanne overvejelser ønsker strukturhistorikerne ikke at gå ind $i$, idet en produktion af utopier ville være at overskride teoriens eget grundlag, fordi det ville ende i en meta-teoretisk diskurs. Jeg mener, der her er tale om en svaghed, fordi sportens fascination og tiltrækning vil være svær at få fat på.

Selv om Bohr ikke kunne forklare alt med fysikken, så henfaldt han dog ikke af den grund til en meta-fysik. Gud være lovet!

I stedet for at åbne for en videreudvikling i en velargumenteret diskussion, 
indkapsler KC sin utopi og propper den ind, der hvor han ser en mangel. Han sætter den eksisterende viden i skab og lukker døren for at redde sin utopi. Det samme mener jeg sker i ekskursen om kroppen s. 122, hvor KC ikke kan klare at strukturhistorikerne giver ,,fornemmelsen af, at alt kan være lige godt og skidt". Med det sidste årti in mente, kan man måske undre sig over, at KC ikke tager udfordringen op her og spørger sig (sammen med strukturhistorikerne?), hvad der ligger til grund for vores bestemmelse af godt og skidt. Hvem er de, der sidder inde med en sådan viden?

Andet afsnit i bogen omhandler fodboldspillets historie. Meget af det KC videregiver (han støtter her igen mest til andres forskning), vidste jeg ikke på forhånd særlig meget om. Derfor blev jeg også revet med af læsningen. Og det er interessant læsning, både den historiske udvikling i den store fodboldnation England og den i Danmark. Det undrede mig i øvrigt, at JBU først var stiftet som cricket union (1895), for derefter at tage fodboldspillet op i 1902, al den stund, at cricket herhjemme stadig er minimalt udbredt. En del forklares senere i bogen, hvor KC kommer ind på sammenligninger mellem samfundsudviklingen og fodboldens udvikling. Han giver her noglë bud på, hvorfor fodbold blev en massesport. Det historiske afsnit udmærker sig også ved kuriositeter såsom sammenligninger med sydøstasiatiske former for boldspil - det krydrer beskrivelserne.

I det tredie afsnit om det nuværende fodboldspil, har KC nogle gode indslag. Del tre omhandler tre overordnede emner: fodboldspillet som aktivitet, omgivelserne og tilskueraktiviteten.

Første del af KCs ekskurs om kroppen er virkelig godt. KC falder nemlig ikke i dér, hvor mange andre gør, når de taler om kroppen, som om vi alle mente det samme. Faktisk viser KC, at det netop ikke er tilfældet.

Også i den mere essayistiske form som i afsnittet om ,Mandlighed og fodbold" er KC på hjemmebane. Her lader han mange overvejelser stå åbne og er på den måde fremadpegende. KC definerer ikke, hvad mandlighed er „,da mandlighed ikke er just empirisk målbar (og sikkert ikke interessant som sådan)". Parentesen er vigtig, idet amerikanske forskere faktisk mener at kunne måle maskulinitet og femininitet hos sportsudøvere. Jeg mener ikke, vi kan tage det alvorligt, men hvis vi kunne (og det gør amerikanerne jo nok), så må vi som KC netop sige, at det er særdeles uinteressant.

I et forsøg på at vise, hvordan mandetyperne har udviklet sig gennem tiderne, bruger KC S. Kieselberg, som beskriver en trefaset udvikling: fra den traditionelle borgerlige manderolle over den, der opstod med overgangen til monopolkapitalisme til den nye, 'bløde' mand. Og så må det tilføjes, at 
Kieselberg allerede er forældet, idet en helt ny mand er trådt ind på scenen. Omend fodboldspillet ifølge KC ikke kan styrke og bekræfte 70-ernes 'bløde' mand, som han mener det har bekræftet de foregående mandetyper, så kan det måske bekræfte 80-ernes? Eller vil han snarere vælge trimcentrene?

Afsnittet om fascination er også et af KCs stærkere bidrag. Her beskriver og diskuterer han de små og store oplevelser i fodboldspillet. Blandt beskrivelserne er den oplevelse, som vi også kender under navnet ,,peak experience", hvor alt smelter sammen til ét stort hele. Hvor tingene bare sker mens jeg'et synes sat ud af funktion. En form for jeg-løshed betegner nogle den med. Dette kan dog ikke helt være tilfældet, påpeger KC, idet der jo stadig er et jeg, der reflekterer og altså har haft oplevelsen. KC mener at kunne hente forklaringen på fascinationen af de store oplevelser $\mathrm{i}$ den østlige Zen-buddhisme, omend han også understreger - og det er vigtigt - det betænkelige $i$ at hente sin forklaring $i$ en helt anden videnskabstradition. Jeg kan nu heller ikke se, at KC forklarer noget. Snarere er det en uddybende beskrivelse af fænomenet. Hvad det er, der fascinerer os $\mathrm{i}$ alle de forskellige elementer $\mathrm{i}$ fodboldspillet, som KC beskriver, står endnu åbent. Og i øvrigt: Hvad er fascination i det hele taget for noget?

Fire sider er ikke meget til anmeldelse af en bog på 171, hvis retfærdighed skal ske fyldest. Det skal den så ikke, så fodboldinteresserede (altså dem, der ikke kun er interesseret $\mathrm{i}$ at spille og se fodbold, men også i at vide noget) må selv læse. Omend der ikke sker så meget nyt i bogen, så er der mange gode indlæg. 